\title{
Polycaprolactone Electrospun Fiber Scaffold Loaded With iPSCs-NSCs And ASCs As A Novel Tissue Engineering Scaffold For The Treatment Of Spinal Cord Injury [Corrigendum]
}

\author{
Zhou X, Shi G, Fan B, et al. Int $J$ Nanomedicine. \\ 2018;13:6265-6277.
}

On page 6273 , Figure $4 \mathrm{C}(\mathrm{a})$ should be presented as follows:

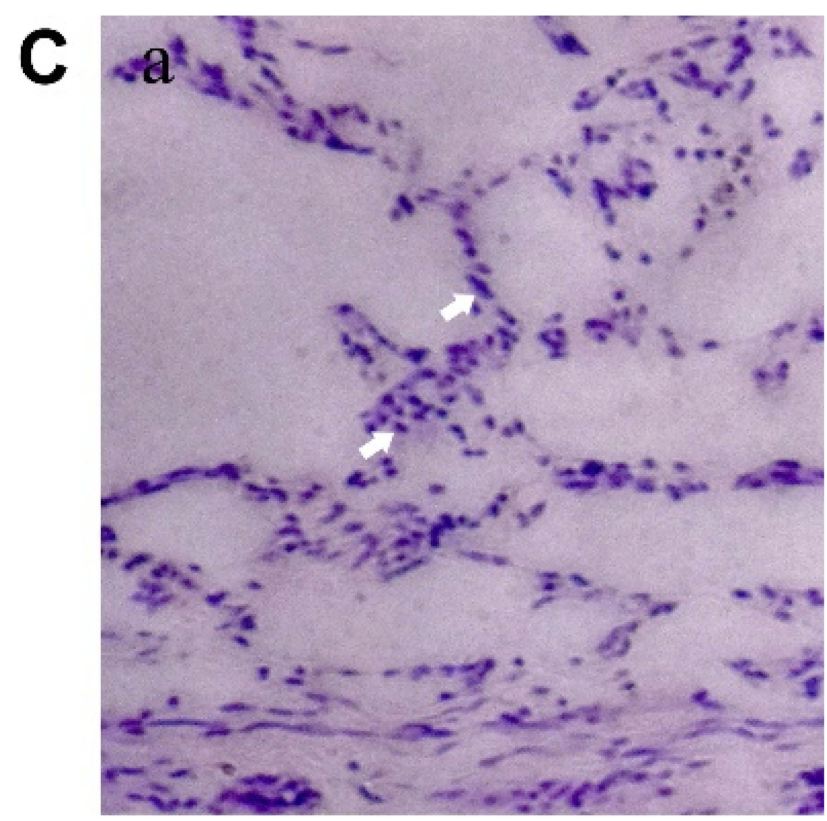

Figure 4 Axonal regeneration and remyelination of transplanted cells in injured spinal cord.

Notes: (A) Spinal cord transection and transplantation. Scale bar $=0.5 \mathrm{~cm}$. (B) Gross morphology and cavity formation of spinal cord tissue. (C) H\&E staining of Group I (a), Group 2 (b), Group 3 (c), and Group 4 (d). Arrows: infiltrated cells in spinal cord. Scale bar $=100 \mu \mathrm{m}$.

Abbreviation: H\&E, hematoxylin-eosin.
Following a review of our data post-publication, we found the image was incorrectly uploaded and used for Figure 4C(a). The correct image is shown in this corrigendum. This correction of the image has no impact to the findings of the study. The authors apologize for this error.

\section{Publish your work in this journal}

The International Journal of Nanomedicine is an international, peerreviewed journal focusing on the application of nanotechnology in diagnostics, therapeutics, and drug delivery systems throughout the biomedical field. This journal is indexed on PubMed Central, MedLine, CAS, SciSearch ${ }^{\circledR}$, Current Contents ${ }^{\mathbb{B}} /$ Clinical Medicine,

Journal Citation Reports/Science Edition, EMBase, Scopus and the Elsevier Bibliographic databases. The manuscript management system is completely online and includes a very quick and fair peer-review system, which is all easy to use. Visit http://www.dovepress.com/ testimonials.php to read real quotes from published authors. 